(C) The Authors 2012

\title{
High-fat diet feeding induces a depot-dependent response on the pro-inflammatory state and mitochondrial function of gonadal white adipose tissue
}

\author{
E. Amengual-Cladera ${ }^{1,2}$, I. Lladó ${ }^{1,2}$, A. M. Proenza ${ }^{1,2}$ and M. Gianotti ${ }^{1,2 *}$ \\ ${ }^{1}$ Grup Metabolisme Energètic i Nutrició, Departament de Biologia Fonamental i Ciències de la Salut, Institut Universitari \\ d'Investigació en Ciències de la Salut (IUNICS), Universitat de les Illes Balears, Carretera Valldemossa km 7.5, E-07122 \\ Palma de Mallorca, Spain \\ ${ }^{2}$ CIBERobn (CBO6/O3), Instituto de Salud Carlos III, Spain \\ (Submitted 10 November 2011 - Final revision received 27 February 2012 - Accepted 27 February 2012 - First published online 1 May 2012)
}

\section{Abstract}

Obesity has been related to a chronic pro-inflammatory state affecting white adipose tissue (WAT), which has a great impact on carbohydrate, lipid and energy metabolism. In turn, the dysregulation of adipokine secretion derived from the accumulation of excess lipids in adipocytes further contributes to the development of insulin resistance and can be associated with mitochondrial dysfunction. The aim of the present study was to determine whether sexual dimorphism found in the systemic insulin sensitivity profile is related to sex differences in a high-fat diet (HFD) response of gonadal WAT at mitochondrial function and inflammatory profile levels. Wistar rats (10 weeks old) of both sexes were fed a control pelleted diet (3\% (w/w) fat; $n 8$ for each sex) or a HFD (24\% (w/w) fat; $n 8$ for each sex). Serum insulin sensitivity markers, mRNA expression levels of inflammatory factors and the protein content of insulin and adiponectin signalling pathways were analysed, as well as the levels of the main markers of mitochondrial biogenesis, antioxidant defence and oxidative damage. In the present study, the periovarian depot exhibits a greater expandability capacity, along with a lower hypoxic and pro-inflammatory state, without signs of mitochondrial dysfunction or changes in its dynamics. In contrast, epididymal fat has a much more pronounced pro-inflammatory, hypoxic and insulin-resistant profile accompanied by changes in mitochondrial dynamics, probably associated with HFD-induced mitochondrial dysfunction. Thus, this explains the worse serum insulin sensitivity profile of male rats.

Key words: Obesity: Mitochondrial biogenesis: Insulin sensitivity: Adipokines: Rats

White adipose tissue (WAT) has become an important target for the treatment of metabolic complications associated with obesity, since either the impairment of its capacity to buffer excess lipids or the dysregulation of its endocrine function has been related to the development of a chronic pro-inflammatory state and insulin resistance typical of the onset of obesity. It has been found that adipokines are closely related to the maintenance of different metabolic processes such as the regulation of energy homeostasis, insulin sensitivity and lipid/carbohydrate metabolism ${ }^{(1)}$, and are also linked to the regulation of some immune factors ${ }^{(2)}$. Some pro-inflammatory and atherothrombotic adipokines/cytokines such as leptin, resistin, IL-6, TNF- $\alpha$ and plasminogen activator inhibitor-1 (PAI-1) are increased in obesity, whereas the antiinflammatory adipokine adiponectin tends to be decreased ${ }^{(3)}$.
Obesity also disturbs the equilibrium existing between the different cell types that constitute $\mathrm{WAT}^{(4-6)}$, and favours a hypoxic environment derived from the scarce vascularisation of this tissue, which is able to induce macrophage infiltration $^{(7,8)}$. In fact, high-fat diet (HFD)-induced obesity has been extensively linked to a chronic pro-inflammatory state, in which cytokine/adipokine expression is disrupted, addressing macrophage activation as a key factor in the development of insulin resistance ${ }^{(9,10)}$. Indeed, some inflammatory factors such as TNF- $\alpha^{(11)}$ induce the serine phosphorylation of insulin receptor substrate 1 , inhibiting its action. Therefore, inflammation has become a crucial factor in the progression of obesity, since the accumulation of activated macrophages in adipose tissue and, subsequently, the secretion of pro-inflammatory factors contribute to the development of insulin resistance ${ }^{(12)}$.

Abbreviations: adipoR1, adiponectin receptor 1; Akt, Ser/Thr kinase A; AMPK, AMP-activated protein kinase; COXII, cytochrome $c$ oxidase subunit II; COXIV, cytochrome $c$ oxidase subunit IV; Fis1, mitochondrial fission 1 ; HFD, high-fat diet; HIF-1 $\alpha$, hypoxia-inducible factor $1 \alpha$; HOMA-IR, homeostasis model assessment of insulin resistance; Mfn1, mitofusin 1; Mfn2, mitofusin 2; mtDNA, mitochondrial DNA; PAI-1, plasminogen activator inhibitor-1; pAkt, phosphorylated Ser/Thr kinase A; pAMPK, phosphorylated AMP-activated protein kinase; WAT, white adipose tissue. 
Defective mitochondrial function has also been reported in different tissues of insulin-resistant animals ${ }^{(13-15)}$. However, the relationship between mitochondrial dysfunction and the development of insulin resistance is only beginning to be understood in WAT. Mitochondrial biogenesis, a process that involves mitochondrial proliferation (increase in the number of mitochondria) and differentiation (increase in mitochondrial function capacity), is directed to counteract mitochondrial dysfunction and is also related to the improvement of insulin sensitivity ${ }^{(16,17)}$. In addition, mitochondria constantly fuse (fusion process) and divide (fission process), and an imbalance of these two processes dramatically alters the overall mitochondrial morphology. Several proteins have been seen to be involved in these processes, such as mitofusin 1 and 2 (Mfn1 and 2) $)^{(18)}$ and mitochondrial fission 1 (Fis1) ${ }^{(19)}$. A HFD can induce an increase in oxidative capacity due to the high amount of oxidative substrates available, although, in turn, the accumulation of oxidative intermediates such as ceramides as well as reactive oxygen species production has been related to the development of insulin resistance ${ }^{(20,21)}$. In fact, a close association between HFD-induced obesity and oxidative stress has also been described ${ }^{(22)}$, which leads to an irregular production of adipokines, contributing to the development of the metabolic syndrome ${ }^{(23)}$.

Therefore, detailed knowledge of the relationship between mitochondrial dysfunction and the development of insulin resistance in WAT is of great interest. Taking this background into account and the evidence achieved by our group in tissues such as liver $^{(14,24)}$, muscle ${ }^{(25,26)}$, brown adipose tissue $\mathrm{e}^{(27-29)}$ and brain $^{(30)}$, where female rats have greater mitochondrial function, lower oxidative damage and also higher insulin sensitivity than males, the aim of the present study was to determine whether sexual dimorphism found in the systemic insulin sensitivity profile is related to sex differences in a HFD response of gonadal WAT at mitochondrial function and inflammatory profile levels.

\section{Materials and methods}

\section{Animals and diets}

A total of sixteen male and sixteen female Wistar rats of 10 weeks of age (Charles River) were each divided into two dietary groups with a similar mean body weight (332 (sem 4) g for males and 217 (sem 2) g for females). For 26 weeks, a control group ( $n$ 8) was fed a standard pelleted diet (Panlab) containing 19\% of total energy $(14162 \mathrm{~kJ} / \mathrm{kg}$ diet; $2 \cdot 9 \%$ fat, $\mathrm{w} / \mathrm{w}$ ) as protein, $73 \%$ as carbohydrate and $8 \%$ as lipid, and a cafeteria diet group ( $n$ 8) was fed a HFD to generate a diet-induced obesity model. The cafeteria diet was composed of cookies, pork liver pâté, fresh bacon, chocolate and ensaïmada (a typical Majorcan pastry), reaching an energy content of $16217 \mathrm{~kJ} / \mathrm{kg}$ diet, where protein, carbohydrate and lipids represent 13, 33 and 54\%, respectively. Rats were fed ad libitum with the standard diet (control group) and with the standard diet plus cafeteria-diet (HFD group). The amount consumed of each high-fat food and its nutrient composition is given in Table 1 . The animals were weighed monthly and energy intake was measured at 22 weeks of dietary treatment, as reported previously ${ }^{(31)}$. The rats were killed by decapitation at 36 weeks of age and serum was collected and frozen in liquid $\mathrm{N}_{2}$ and stored at $-70^{\circ} \mathrm{C}$ until analysed. Gonadal fat depots were removed and a piece of tissue was used to isolate adipocytes. The rest of the tissue was frozen at $-70^{\circ} \mathrm{C}$ until analysed. The animals were housed two per cage and always kept at $22^{\circ} \mathrm{C}$ on a $12 \mathrm{~h}$ light $-12 \mathrm{~h}$ dark cycle, and the experiments were performed in accordance with the general guidelines approved by our institutional ethics committee and European Union regulations (2003/65/CE and 86/609/CEE).

\section{Adipocyte isolation and culture}

Epididymal and periovarian fat depots were removed under aseptic conditions from the control and HFD male and female Wistar rats, respectively, after decapitation. Adipocyte isolation was performed using collagenase digestion according to Landt et al. $^{(32)}$, with minor modifications. Briefly, fat pads were cut into pieces with scissors in buffer ( $\mathrm{pH} 7 \cdot 4)$ containing 5 mM-Dglucose, bovine serum albumin (20 g/l), $135 \mathrm{~mm}-\mathrm{NaCl}, 2 \cdot 2 \mathrm{~mm}-$

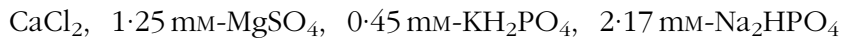
and $10 \mathrm{~mm}$-HEPES. Digestion was carried out with $2.5 \mathrm{mg}$ type II collagenase in $2 \mathrm{ml}$ of buffer/g tissue (specific activity, $760 \times 10^{-5} \mathrm{katal} / \mathrm{g}$; Sigma Chemical Company), at $37^{\circ} \mathrm{C}$ with gentle shaking at sixty cycles per min for $45 \mathrm{~min}$. A $600 \mu \mathrm{m}$

Table 1. Food and nutrient composition*

(Mean values with their standard errors)

\begin{tabular}{|c|c|c|c|c|c|c|c|c|}
\hline \multirow[b]{2}{*}{ HFD feeding } & \multicolumn{2}{|c|}{$\begin{array}{l}\text { Total food amount } \\
\text { (g/100 g diet) }\end{array}$} & \multicolumn{6}{|c|}{ Nutrient composition ( $\mathrm{g} / 100 \mathrm{~g}$ food) } \\
\hline & Mean & SEM & Protein & Carbohydrate & Lipids & MUFA & PUFA & SFA \\
\hline Pork liver pâté & $26 \cdot 1$ & $2 \cdot 1$ & 11.9 & $2 \cdot 70$ & 29.5 & $7 \cdot 22$ & 0.13 & 4.85 \\
\hline $\begin{array}{l}\text { Ensaïmada (typical } \\
\text { Majorcan pastry) }\end{array}$ & $15 \cdot 2$ & 1.9 & $8 \cdot 10$ & $50 \cdot 6$ & $29 \cdot 1$ & 1.40 & 0.53 & $1 \cdot 21$ \\
\hline Fresh bacon & $46 \cdot 1$ & $2 \cdot 7$ & $17 \cdot 3$ & - & $29 \cdot 9$ & 6.09 & 1.62 & $6 \cdot 37$ \\
\hline Cookies & $2 \cdot 80$ & 0.89 & $5 \cdot 82$ & $68 \cdot 0$ & $21 \cdot 3$ & 0.14 & 0.02 & 0.21 \\
\hline Chocolate & 4.35 & 0.97 & 6.70 & $60 \cdot 0$ & 30.0 & 0.42 & 0.05 & 0.77 \\
\hline Standard pelleted diet & 5.09 & 1.67 & $18 \cdot 7$ & 73.3 & 8.00 & 0.06 & 0.07 & $0 \cdot 10$ \\
\hline
\end{tabular}

HFD, high-fat diet.

* Of the animals used in the study, twelve animals per group were chosen to determine energy intake. Total food amount is calculated as the amount of each HFD component consumed expressed per $100 \mathrm{~g}$ of diet consumed. As no sex differences were found in the consumption of the HFD components, the total food amount values are expressed as mean values with their standard errors taking into account the rats of both sexes. 
nylon mesh (Spectrumlabs) was used to separate isolated adipocytes from the undigested tissue. After washing three times with buffer, adipocytes were resuspended in Dulbecco's modified Eagle's medium with glucose $(4.5 \mathrm{~g} / \mathrm{l}), 10 \%$ fetal bovine serum and $1 \%$ penicillin and streptomycin, and then incubated for $30 \mathrm{~min}$ at $37^{\circ} \mathrm{C}$. Finally, six-well culture plates that had been previously covered with $500 \mu$ l of Matrigel (BD Biosciences) were used to keep the adipocytes in culture. Then, $150 \mu \mathrm{l}$ of the adipocyte suspension (2:1 ratio of packed cells to media) were plated in each well with $2 \mathrm{ml}$ of Dulbecco's modified Eagle's medium supplemented with $10 \%$ fetal bovine serum in $5 \% \mathrm{CO}_{2}$ in air at $37^{\circ} \mathrm{C}$.

Isolated adipocytes were treated with $\mathrm{H}_{2} \mathrm{O}_{2}$ to induce an acute oxidative stress. $\mathrm{H}_{2} \mathrm{O}_{2}(100 \mu \mathrm{M})$ was added to Dulbecco's modified Eagle's medium supplemented with bovine serum albumin instead of fetal bovine serum to avoid interference. After $18 \mathrm{~h}$ of treatment, the media were collected and cells were harvested and frozen at $-80^{\circ} \mathrm{C}$ until analysed.

The effect of the $\mathrm{H}_{2} \mathrm{O}_{2}$ treatment on adipocyte viability was tested using the CytoTox $96^{\circledR}$ Non-Radioactive Cytotoxicity Assay (Promega), a colorimetric method for measuring lactate dehydrogenase activity in the culture medium as a result of its release upon cell lysis. All reagents were prepared according to the manufacturer's instructions. In response to the $\mathrm{H}_{2} \mathrm{O}_{2}$ treatment, no differences between the groups were observed in cellular viability, which was $96 \%$ as a mean value of the four groups studied.

\section{Oral glucose tolerance test}

The oral glucose tolerance test was performed on the week before killing. Rats were fasted for a $12 \mathrm{~h}$ period and then glucose $(2 \mathrm{~g} / \mathrm{kg}$ body weight) was given orally. Blood was collected from the tail vein before glucose administration and after 15, 60 and $120 \mathrm{~min}$. Glucose concentrations were measured using the Accutrend ${ }^{\circledR}$ system (Roche Diagnostics).

Serum parameters, sample preparation and tissue composition

Serum glucose levels were measured by the Accutrend ${ }^{\circledR}$ GCT system (Roche Diagnostics). Insulin (Mercodia) and the adipokines leptin, total and high-molecular-weight adiponectin and resistin (Biovendor) were determined using enzyme immunoassay kits. In order to establish insulin resistance, the homeostasis model assessment of insulin resistance (HOMAIR) was calculated, as described previously ${ }^{(33)}$, as follows:

$$
\begin{aligned}
\text { HOMA-IR }= & (\text { blood fasting glucose }(\mathrm{mm}) \\
& \times \text { blood fasting insulin }(\mu \mathrm{U} / \mathrm{ml})) / 22 \cdot 5 .
\end{aligned}
$$

Briefly, $350 \mathrm{mg}$ of the remaining epididymal or periovarian WAT, respectively, were homogenised in $1 \mathrm{ml}$ of (STE) buffer (250 mm-sucrose, 5 mm-Tris-HCl and 2 mm-EGTA, pH 7.4). An aliquot of each homogenate was frozen $\left(-20^{\circ} \mathrm{C}\right)$ with protease and phosphatase inhibitors $(10 \mu \mathrm{m}$-leupeptin, $10 \mu \mathrm{m}$-pepstatin, $0 \cdot 2 \mathrm{~mm}$-phenylmethylsulfonyl fluoride (PMSF) and $0.2 \mathrm{~mm}$-ortovanadate) for Western blot analysis.

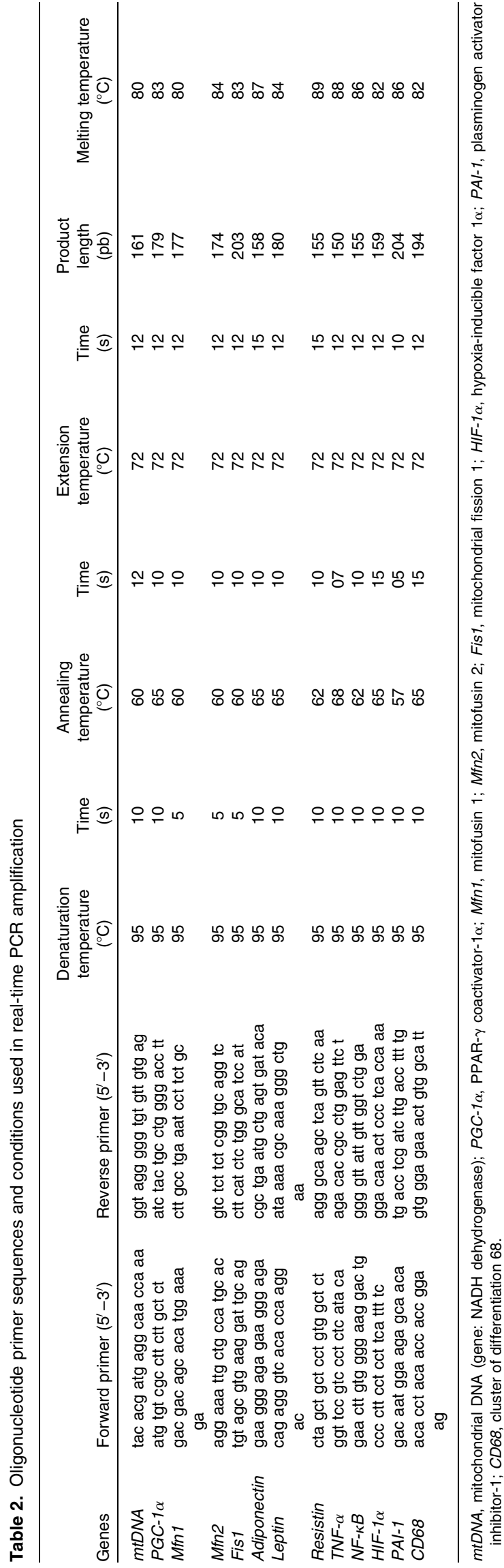


The total DNA of gonadal fat pads and isolated adipocytes ${ }^{(34)}$ as well as the total protein content ${ }^{(35)}$ in gonadal WAT were assessed. Mitochondrial DNA (mtDNA) extraction and semi-quantification was carried out in tissue homogenates according to a previously described method ${ }^{(36)}$, with some modifications ${ }^{(29)}$. Primer sequences are shown in Table 2.

\section{Western blot analysis for markers of mitochondrial biogenesis and function, antioxidant enzymes and markers of insulin and adiponectin signalling pathways}

Equal amounts of protein $(40 \mu \mathrm{g})$ from homogenates, which had been frozen with protease and phosphatase inhibitors, were fractionated on 8, 10, 12 and 15\% SDS-PAGE gels and electrotransferred onto a nitrocellulose filter. Membranes were blocked in 5\% non-fat dry milk in PBS-Tween for $1 \mathrm{~h}$ and incubated overnight with a primary antibody. Rabbit antisera against mitochondrial transcription factor A were kindly provided by Inagaki ${ }^{(37)}$. Primary antibodies were supplied by Santa Cruz Biotechnology (anti-cytochrome $c$ oxidase subunit II (anti-COXII) and GLUT4, ref. sc-23984 and sc-7938, respectively), MitoSciences (anti-cytochrome $c$ oxidase subunit (anti-COXIV), ref. MS407), Alpha Diagnostic International (anti-carnitine palmitoyltransferase I, 4-hydroxy-2-nonenal and adiponectin receptor 1 (AdipoR1), ref. CPT1M11-A, HNE-11S and ADIPOR12-A, respectively), BD Biosciences (anti-insulin receptor $\beta$, ref. 611277), Cell Signaling (anti-IRS1, phosphorylated AMP-activated protein kinase (pAMPK), AMP-activated protein kinase (AMPK), phosphorylated Ser/ Thr kinase A (pAkt) and Ser/Thr kinase A (Akt), ref. 10/ 2008, 2531, 01/2009, 9272 and 9271, respectively) and Calbiochem (anti-catalase, mitochondrial superoxide dismutase, cytosolic superoxide dismutase and glutathione peroxidase, ref. 219010, 574596, 574597 and ST1000, respectively). Afterwards, incubation with a secondary antibody was performed for $1 \mathrm{~h}$. Development of immunoblots was performed using an enhanced chemiluminescence kit from Bio-Rad. Bands were obtained using the Chemidoc XRS system (Bio-Rad), and quantification was done with Quantity One software (BioRad). Autoradiograms revealed an apparent molecular mass of $16 \mathrm{kDa}$ for COXIV and cytosolic superoxide dismutase, and $60 \mathrm{kDa}$ for Akt, pAkt, AMPK and pAMPK. Moreover, a molecular weight of $21,22 \cdot 5,25,28,42 \cdot 5,54,65,88,95$ and 180 was observed for COXII, glutathione peroxidase, mitochondrial superoxide dismutase, mitochondrial transcription factor A, AdipoR1, insulin-responsive GLUT4, catalase, carnitine palmitoyltransferase I, insulin receptor $\beta$ and insulin receptor substrate 1 , respectively.

\section{Measurement of carbonyl group content and 4-hydroxy-2-nonenal content}

As a marker of protein oxidation, protein carbonyl group content was determined in homogenates of gonadal fat depots by immunoblot analyses using the Oxyblot ${ }^{\mathrm{TM}}$ Protein Oxidation Detection Kit (Chemicon International) according to the manufacturer's instructions with minor modifications $^{(30)}$. 4-Hydroxy-2-nonenal content was assessed by Western blot as a marker of lipid peroxidation ${ }^{(38)}$.

\section{Real-time RT-PCR}

Total RNA was obtained from $200 \mathrm{mg}$ of WAT using TriPure $^{\circledR}$ isolation reagent and quantified using a spectrophotometer set at $260 \mathrm{~nm}$. RNA purity was assessed by the 260:280 nm ratio.

Briefly, $1 \mu \mathrm{g}$ of the total RNA was reverse transcribed to complementary DNA for $60 \mathrm{~min}$ at $42^{\circ} \mathrm{C}$, with $25 \mathrm{U}$ MuLV RT in a $10 \mu \mathrm{l}$ volume of retrotranscription reaction mixture containing $10 \mathrm{~mm}-$ Tris $-\mathrm{HCl}, 50 \mathrm{~mm}-\mathrm{KCl}, 0 \cdot 1 \%$ Triton $\mathrm{X}^{\circledR}-100$,

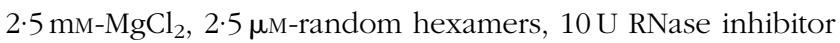
and $500 \mu \mathrm{M}$ of each dNTP in a Gene Amp 9700 thermal cycler (Applied Biosystems). Each complementary DNA solution was diluted (1:10) and aliquots were frozen $\left(-20^{\circ} \mathrm{C}\right)$ until the PCR were performed.

Real-time PCR was carried out for the mRNA of PPAR- $\gamma$ coactivator- $1 \alpha$, a regulator of mitochondrial biogenesis, as well as for those of adiponectin, leptin and resistin, the inflammatory markers NF-кB, TNF- $\alpha$ and CD68, the markers of hypoxia and impaired fibrinolysis, such as hypoxia-inducible factor $1 \alpha(\mathrm{HIF}-1 \alpha)$ and PAI-1, and the markers of mitochondrial fusion, such as Mfn1 and Mfn2, and mitochondrial fission such as Fis1. Oligonucleotide primer sequences (Table 1) were obtained from Primer3 and tested with IDT

Table 3. Body weight, energy intake and adiposity index

(Mean values with their standard errors, $n 8$ )

\begin{tabular}{|c|c|c|c|c|c|c|c|c|c|}
\hline & \multicolumn{4}{|c|}{ Males } & \multicolumn{4}{|c|}{ Females } & \multirow[b]{3}{*}{ ANOVA* } \\
\hline & \multicolumn{2}{|c|}{ Control } & \multicolumn{2}{|c|}{ HFD } & \multicolumn{2}{|c|}{ Control } & \multicolumn{2}{|c|}{ HFD } & \\
\hline & Mean & SEM & Mean & SEM & Mean & SEM & Mean & SEM & \\
\hline Body weight (g) & 552 & 6 & 669 & 6 & 284 & 6 & 423 & 13 & S, D \\
\hline Body-weight gain $(\mathrm{g})$ & 214 & 5 & 333 & 5 & 75 & 5 & 204 & 15 & S, D \\
\hline Energy intake $\left(\mathrm{kJ} / \mathrm{kg}^{0.75} \mathrm{~d}\right)$ & $594 \cdot 13$ & $20 \cdot 92$ & 987.42 & 8.37 & 853.54 & $41 \cdot 84$ & $1071 \cdot 10$ & 92.05 & S, D \\
\hline Adiposity index (g/100 g animal) $\dagger$ & $10 \cdot 4$ & 0.9 & $16 \cdot 1 \ddagger$ & 0.7 & $7 \cdot 39 \S$ & 0.67 & $17 \cdot 4 \ddagger$ & 1.4 & $D, S \times D$ \\
\hline
\end{tabular}

HFD, high-fat diet; S, sex effect; D, diet effect; $S \times D$, sex and diet interactive effect.

${ }^{*} P<0.05$.

† Adiposity index is the sum of inguinal, gonadal, mesenteric and retroperitoneal depot weights relative to $100 \mathrm{~g}$ of body weight.

$\ddagger$ Mean values were significantly different for the HFD group from those of the control group $(P<0.05$; Student's $t$ test).

$\S$ Mean value was significantly different for females from that of males $(P<0.05$; Student's $t$ test). 
Table 4. Gonadal white adipose tissue (WAT) composition

(Mean values with their standard errors, $n 8$ )

\begin{tabular}{|c|c|c|c|c|c|c|c|c|c|}
\hline & \multicolumn{4}{|c|}{ Epididymal WAT } & \multicolumn{4}{|c|}{ Periovarian WAT } & \multirow[b]{3}{*}{ ANOVA* } \\
\hline & \multicolumn{2}{|c|}{ Control } & \multicolumn{2}{|c|}{ HFD } & \multicolumn{2}{|c|}{ Control } & \multicolumn{2}{|c|}{ HFD } & \\
\hline & Mean & SEM & Mean & SEM & Mean & SEM & Mean & SEM & \\
\hline \multicolumn{10}{|l|}{ Tissue weight } \\
\hline $\mathrm{g}$ & $15 \cdot 5$ & $1 \cdot 1$ & $24 \cdot 3 \dagger$ & $1 \cdot 2$ & $9 \cdot 29 \ddagger$ & 0.46 & $24 \cdot 1 \dagger$ & 0.9 & $\mathrm{~T}, \mathrm{D}, \mathrm{T} \times \mathrm{D}$ \\
\hline $\mathrm{g} / 100 \mathrm{~g}$ animal & 2.65 & 0.21 & $3.85 \dagger$ & 0.17 & 2.94 & 0.142 & $5.95 \dagger \ddagger$ & $0 \cdot 21$ & $\mathrm{~T}, \mathrm{D}, \mathrm{T} \times \mathrm{D}$ \\
\hline Protein (mg/g tissue) & $5 \cdot 89$ & 0.46 & 5.49 & 0.29 & $7.53 \ddagger$ & 0.45 & $5.54 \dagger$ & 0.42 & $\mathrm{~T}, \mathrm{D}, \mathrm{T} \times \mathrm{D}$ \\
\hline DNA (mg/g tissue) & 0.371 & 0.018 & 0.200 & 0.015 & $0 \cdot 271$ & 0.027 & 0.171 & 0.005 & $\mathrm{~T}, \mathrm{D}$ \\
\hline Protein $v$. DNA (mg protein/mg DNA) & $12 \cdot 6$ & 0.6 & $18 \cdot 9$ & $2 \cdot 1$ & $18 \cdot 2$ & 1.6 & $25 \cdot 7$ & 0.9 & $\mathrm{~T}, \mathrm{D}$ \\
\hline
\end{tabular}

HFD, high-fat diet; $T$, tissue effect; $D$, diet effect; $T \times D$, tissue and diet interactive effect

${ }^{*} P<0.05$.

† Mean values were significantly different for the HFD group from those of the control group $(P<0.05$; Student's $t$ test).

$\ddagger$ Mean values were significantly different for periovarian WAT from those of epididymal WAT $(P<0.05$; Student's $t$ test $)$.

OligoAnalyser 3.0. Finally, a basic local alignment search tool (NCBI Blast) revealed that the primer sequence homology was obtained only for the target genes. Real-time PCR was performed using the LightCycler SYBR Green technology on a LightCycler rapid thermal cycler (Roche Diagnostics). Each reaction contained $1 \mu \mathrm{l}$ LightCycler-FastStart DNA Master $\mathrm{SYBR}^{\mathrm{TM}}$ Green I (containing FastStart Taq DNA polymerase, dNTP mix, reaction buffer and SYBR Green I dye), $0.5 \mu \mathrm{m}$ of the sense and antisense specific primers, $2 \mathrm{~mm}-\mathrm{MgCl}_{2}$ and $3 \mu \mathrm{l}$ of the complementary DNA dilution in a final volume of $10 \mu \mathrm{l}$. The amplification programme consisted of a preincubation step for denaturation of template complementary DNA $\left(95^{\circ} \mathrm{C}, 10 \mathrm{~min}\right)$, followed by forty cycles consisting of a denaturation, an annealing and an extension step in the conditions shown in Table 2 . After each cycle, fluorescence was measured at $72^{\circ} \mathrm{C}$. Product specificity was confirmed in the initial experiments by agarose gel electrophoresis and routinely by melting curve analysis.

\section{Statistical analysis}

All data are expressed as mean values with their standard errors of eight animals per group. $C_{\mathrm{t}}$ values of real-time PCR were analysed taking into account the efficiency of the reaction and referring the results to the total DNA amount, using GenEx Standard software (MultiDAnalises). Statistical differences between the groups were analysed by two-way ANOVA to study tissue or sex, and diet effects. Additionally, when there was an interactive effect between tissue and diet or between sex and diet, a post hoc comparison by Student's $t$ test was applied. A $P$ value less than 0.05 was considered statistically significant. A statistical software package (SPSS 17.0 for Windows; SPSS, Inc.) was used to perform all statistical analyses.

\section{Results}

Energy intake, body and white adipose tissue weight and tissue composition

The HFD induced an increase in energy intake (Table 3 ) in both sexes which led to a rise in both body weight and adiposity index, especially in female rats. In fact, although the same percentage of adiposity was reached both in male and female rats, the increase was higher in females (2.4- $v$. 1.7-fold).

Both epididymal and periovarian WAT weight (Table 4) relative to body weight increased with dietary treatment, reaching higher values in the periovarian depot compared with the epididymal one. The total tissue weight was modified with dietary treatment, showing an increase by $160 \%$ in the periovarian depot and by $57 \%$ in the epididymal one.

Protein content was significantly higher in the periovarian depot of the control animals than in the epididymal one, whereas HFD feeding matched the levels of both depots. The total DNA levels were higher in the epididymal depot compared with the periovarian one, and decreased in both depots after HFD feeding. The protein content per cell was higher in the periovarian depot and increased after HFD feeding in both sexes.

\section{Oral glucose tolerance test}

The present results (Fig. 1) indicate that there is an increase in blood glucose levels in all the experimental groups at 15 min after glucose administration, reaching higher levels in male rats than in female rats. In the control rats, a decrease in

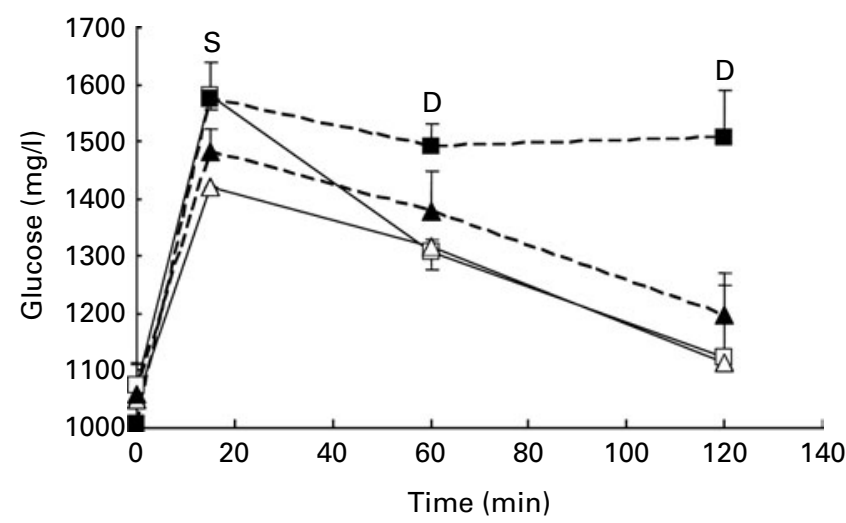

Fig. 1. Oral glucose tolerance curves. Values are means for six animals per group, with their standard errors represented by vertical bars. Mean values were significantly different $(P<0.05$; ANOVA). $\square-$, Control males; ......, high-fat diet (HFD) males; $-\neg$, control females; ......., HFD females; $\mathrm{S}$, sex effect; $\mathrm{D}$, diet effect. 
Table 5. Serum glucose, hormone levels and homeostasis model assessment-insulin resistance (HOMA-IR) ${ }^{\star}$ values (Mean values with their standard errors, $n 8$ )

\begin{tabular}{|c|c|c|c|c|c|c|c|c|c|}
\hline & \multicolumn{2}{|c|}{ Control } & \multicolumn{2}{|c|}{ HFD } & \multicolumn{2}{|c|}{ Control } & \multicolumn{2}{|c|}{ HFD } & \multirow[b]{2}{*}{ ANOVA $\dagger$} \\
\hline & Mean & SEM & Mean & SEM & Mean & SEM & Mean & SEM & \\
\hline Glucose (mM) & $6 \cdot 83$ & 0.29 & $6 \cdot 51$ & 0.37 & $6 \cdot 19$ & 0.63 & 6.44 & 0.43 & NS \\
\hline Insulin $(\mu \mathrm{g} / \mathrm{l})$ & 1.38 & 0.39 & 1.80 & 0.70 & 0.376 & 0.131 & 0.864 & 0.204 & $\mathrm{~S}$ \\
\hline HOMA-IR & 14.6 & $2 \cdot 4$ & 11.4 & $2 \cdot 2$ & $2.45 \S$ & 0.64 & $7 \cdot 01 \mp \S$ & 0.70 & $S, S \times D$ \\
\hline Resistin (ng/ml) & $7 \cdot 63$ & 0.39 & $7 \cdot 89$ & 0.57 & $2 \cdot 85$ & 0.30 & 4.64 & 0.14 & S, D \\
\hline \multicolumn{10}{|c|}{ Adiponectin $(\mu \mathrm{g} / \mathrm{ml})$} \\
\hline Total & $6 \cdot 14$ & 0.2 & $5 \cdot 86$ & 0.3 & $4.87 \S$ & 0.4 & $6.98 \ddagger$ & 0.3 & $S, S \times D$ \\
\hline HMW & 2.99 & 0.47 & 2.49 & 0.61 & 3.89 & $1 \cdot 15$ & $4 \cdot 11$ & 0.72 & $\mathrm{~s}$ \\
\hline Leptin $(\mu \mathrm{g} / \mathrm{ml})$ & $11 \cdot 2$ & 1.5 & $28 \cdot 8$ & $4 \cdot 6$ & $2 \cdot 4$ & 0.3 & $23 \cdot 0$ & 4.6 & S, D \\
\hline
\end{tabular}

HFD, high-fat diet; S, sex effect; $S \times D$, sex and diet interactive effect; D, diet effect; HMW, high molecular weight. ${ }^{*}$ HOMA-IR was calculated as (blood fasting glucose $(\mathrm{mM}) \times$ blood fasting insulin $\left.(\mu \mathrm{U} / \mathrm{ml})\right) / 22.5$. $\dagger P<0.05$.

¥ Mean values were significantly different for the HFD group from those of the control group $(P<0.05$; Student's $t$ test). $\S$ Mean values were significantly different for females from those of males $(P<0.05$; Student's $t$ test).

glucose levels was observed after the peak found at $15 \mathrm{~min}$, whereas, in the HFD-fed rats, glucose levels at 60 and $120 \mathrm{~min}$ were higher than those in the controls, especially in males.

\section{Serum glucose, hormone levels and homeostasis model assessment-insulin resistance values}

No differences between the groups were found in serum glucose levels, either between sexes or in response to the HFD (Table 5). Compared with females, higher systemic insulin values were found in male rats, and a trend to increase after HFD feeding was observed in both sexes, although this did not reach statistical significance. Male control rats exhibited a higher HOMA-IR compared with females, whereas HFD feeding induced an increase in this parameter only in female rats, although this increase was not enough to reach the values observed in males. Male rats showed greater serum resistin levels than females and in response to the HFD, only females showed an increase. The levels of total adiponectin were lower in control female rats than in male rats, increasing after HFD feeding only in females. However, levels of high-molecular-weight adiponectin were higher in female rats compared with male rats, and these did not change with the HFD. Leptin levels were higher in control male rats than in female rats and increased in both sexes after HFD feeding.

\section{mRNA expression of adipokines and inflammatory markers}

Adiponectin expression levels were higher in the periovarian WAT of the control rats (Table 6), and increased after HFD feeding only in the epididymal depot. mRNA levels of leptin and resistin were lower in the periovarian fat compared with the epididymal one and increased after HFD feeding in both depots (Table 6). TNF- $\alpha$, NF-кB and CD68 expression levels did not show differences between the epididymal and periovarian fat, but increased in both depots in response to the HFD, although to a greater extent in the epididymal one. The periovarian depot of the control rats showed greater levels of HIF- $1 \alpha$ and PAI-1, which increased after HFD feeding, although to a lesser extent than those in the epididymal depot (Table 6).

Table 6. mRNA expression of adipokines and inflammatory markers*

(Mean values with their standard errors, $n 8$ )

\begin{tabular}{|c|c|c|c|c|c|c|c|c|c|}
\hline & \multicolumn{4}{|c|}{ Epididymal WAT } & \multicolumn{4}{|c|}{ Periovarian WAT } & \multirow[b]{3}{*}{ ANOVA $\dagger$} \\
\hline & \multicolumn{2}{|c|}{ Control } & \multicolumn{2}{|c|}{ HFD } & \multicolumn{2}{|c|}{ Control } & \multicolumn{2}{|c|}{ HFD } & \\
\hline & Mean & SEM & Mean & SEM & Mean & SEM & Mean & SEM & \\
\hline Adiponectin & $2 \cdot 15$ & 0.28 & $5 \cdot 29 \ddagger$ & $1 \cdot 18$ & $3.51 \S$ & 0.64 & $2.76 \S$ & 0.45 & $T \times D$ \\
\hline Leptin & 3.50 & 0.85 & $10 \cdot 6$ & $2 \cdot 22$ & 1.98 & 0.25 & 3.33 & 0.40 & $\mathrm{~T}, \mathrm{D}$ \\
\hline Resistin & $9 \cdot 19$ & 1.74 & 40.9 & 11.5 & 6.49 & 1.95 & $8 \cdot 14$ & 1.02 & $\mathrm{~T}, \mathrm{D}$ \\
\hline$T N F-\alpha$ & $11 \cdot 7$ & 3.9 & $24 \cdot 2$ & $5 \cdot 5$ & $11 \cdot 3$ & $2 \cdot 2$ & $15 \cdot 7$ & $2 \cdot 6$ & D \\
\hline$N F-\kappa B$ & 2.01 & 0.36 & $5 \cdot 36$ & 1.36 & $3 \cdot 17$ & 0.44 & 3.47 & 0.45 & D \\
\hline$P A l-1$ & 1.75 & 0.19 & $12 \cdot 1 \ddagger$ & $3 \cdot 2$ & $2.47 \S$ & 0.33 & $4.80 \S$ & 1.53 & $\mathrm{D}, \mathrm{T} \times \mathrm{D}$ \\
\hline$H I F-1 \alpha$ & 2.66 & 0.65 & $8.21 \ddagger$ & 1.57 & $5 \cdot 86 \S$ & 0.99 & $6 \cdot 39$ & 0.98 & $\mathrm{D}, \mathrm{T} \times \mathrm{D}$ \\
\hline$C D 68$ & $2 \cdot 80$ & 0.82 & 9.58 & 1.96 & 2.74 & 0.28 & 5.68 & 1.36 & D \\
\hline
\end{tabular}

WAT, white adipose tissue; HFD, high-fat diet; $T \times D$, tissue and diet interactive effect; $\mathrm{T}$, tissue effect; $\mathrm{D}$, diet effect; $P A /-1$, plasminogen activator inhibitor-1; HIF-1 $\alpha$, hypoxia-inducible factor $1 \alpha ; C D 68$, cluster of differentiation 68 . ${ }^{*}$ Levels of the control male rats were set at $100 \%$. $\dagger P<0.05$.

¥ Mean values were significantly different for the HFD group from those of the control group $(P<0.05$; Student's $t$ test). $\S$ Mean values were significantly different for periovarian WAT from those of epididymal WAT $(P<0.05$; Student's $t$ test). 
Table 7. Protein levels of insulin and adiponectin signalling pathway elements of gonadal white adipose tissue (WAT)* (Mean values with their standard errors referred to DNA, $n$ 8)

\begin{tabular}{|c|c|c|c|c|c|c|c|c|c|}
\hline & \multicolumn{4}{|c|}{ Epididymal WAT } & \multicolumn{4}{|c|}{ Periovarian WAT } & \multirow[b]{3}{*}{ ANOVA } \\
\hline & \multicolumn{2}{|c|}{ Control } & \multicolumn{2}{|c|}{ HFD } & \multicolumn{2}{|c|}{ Control } & \multicolumn{2}{|c|}{ HFD } & \\
\hline & Mean & SEM & Mean & SEM & Mean & SEM & Mean & SEM & \\
\hline \multicolumn{10}{|l|}{ Insulin signalling } \\
\hline $\operatorname{IR} \beta(\%)$ & 100 & 13 & 148 & 11 & 223 & 47 & 195 & 30 & $\mathrm{~T}$ \\
\hline IRS1 (\%) & 100 & 25 & 338 & 49 & 162 & 41 & 326 & 59 & $\mathrm{D}$ \\
\hline pAkt (\%) & 100 & 36 & 298 & 19 & 254 & 67 & 278 & 97 & NS \\
\hline Akt (\%) & 100 & 5 & 116 & 10 & 88 & 9 & 131 & 18 & $\mathrm{D}$ \\
\hline pAkt:Akt & 0.48 & 0.21 & 0.67 & $0 \cdot 10$ & 0.98 & 0.30 & 0.55 & 0.14 & NS \\
\hline GLUT4 (\%) & 100 & 12 & 210 & 38 & 145 & 11 & 205 & 11 & D \\
\hline \multicolumn{10}{|c|}{ Adiponectin signalling } \\
\hline AdipoR1 (\%) & 100 & 16 & 83 & 14 & 110 & 10 & 111 & 18 & NS \\
\hline pAMPK (\%) & 100 & 14 & 111 & 11 & $177 \ddagger$ & 12 & $133 \S$ & 14 & $\mathrm{~T}, \mathrm{~T} \times \mathrm{D}$ \\
\hline AMPK (\%) & 100 & 18 & 150 & 18 & 113 & 20 & 157 & 23 & D \\
\hline pAMPK:AMPK & 1.87 & $0 \cdot 10$ & 1.42 & $0 \cdot 19$ & 2.53 & 0.31 & 1.99 & 0.35 & NS \\
\hline
\end{tabular}

\section{Protein levels of insulin and adiponectin signalling}

pathway elements of epididymal and periovarian white adipose tissue

Periovarian fat showed higher expression levels of insulin receptor $\beta$ than epididymal WAT (Table 7), whereas no sex differences were observed in any other element of the insulin signalling pathway. Consumption of the HFD induced an important increase in insulin receptor substrate 1(IRS1), total Akt and GLUT4 protein levels in both depots. No differences were found in either pAkt protein levels or the pAkt:total Akt ratio.

No differences between the groups were observed in protein levels of adiponectin receptor 1 (Table 7). pAMPK protein levels were higher in the periovarian depot than in epididymal fat and decreased after HFD feeding in the former. Consumption of the HFD induced an increase in the levels of total AMPK in both depots and no depot-related differences were observed at baseline. Compared with epididymal fat, the ratio of pAMPK:total AMPK was greater in the

Table 8. mRNA and protein levels of gonadal white adipose tissue markers of mitochondrial biogenesis and function* (Mean values with their standard errors referred to DNA, $n$ 8)

\begin{tabular}{|c|c|c|c|c|c|c|c|c|c|}
\hline & \multicolumn{4}{|c|}{ Epididymal depot } & \multicolumn{4}{|c|}{ Periovarian depot } & \multirow[b]{3}{*}{ ANOVA $\dagger$} \\
\hline & \multicolumn{2}{|c|}{ Control } & \multicolumn{2}{|c|}{ HFD } & \multicolumn{2}{|c|}{ Control } & \multicolumn{2}{|c|}{ HFD } & \\
\hline & Mean & SEM & Mean & SEM & Mean & SEM & Mean & SEM & \\
\hline \multicolumn{10}{|c|}{ Gene expression } \\
\hline$P G C-1 \alpha$ & 4.61 & 0.49 & $9 \cdot 80 \ddagger$ & 1.48 & $6 \cdot 85 \S$ & 1.01 & $7 \cdot 69$ & 0.54 & $\mathrm{D}, \mathrm{T} \times \mathrm{D}$ \\
\hline Mfn1 & $2 \cdot 69$ & 0.78 & $10 \cdot 45 \ddagger$ & $2 \cdot 17$ & $5 \cdot 82$ & 1.74 & $3 \cdot 17 \S$ & 0.28 & $T \times D$ \\
\hline Mfn1:Fis1 & $1 \cdot 27$ & 0.14 & $2 \cdot 06 \ddagger$ & 0.20 & 1.50 & 0.29 & $1.25 \S$ & 0.12 & $T \times D$ \\
\hline Mfn2 & $2 \cdot 89$ & 0.51 & $9 \cdot 27 \ddagger$ & 1.49 & 5.06 & 1.25 & $4.56 \S$ & 0.55 & $\mathrm{D}, \mathrm{T} \times \mathrm{D}$ \\
\hline Mfn2:Fis1 & 1.59 & 0.27 & 1.99 & 0.16 & 1.47 & 0.19 & 1.42 & 0.24 & NS \\
\hline Fis1 & 1.54 & 0.32 & $4.87 \ddagger$ & 0.84 & $4.11 \S$ & 0.65 & 3.33 & 0.45 & $\mathrm{D}, \mathrm{T} \times \mathrm{D}$ \\
\hline \multicolumn{10}{|c|}{ Protein content $(\%)$} \\
\hline TFAM & 100 & 10 & 169 & 22 & 190 & 15 & 218 & 14 & $\mathrm{~T}, \mathrm{D}$ \\
\hline COXII & 100 & 3 & 147 & 19 & 147 & 14 & 189 & 7 & $\mathrm{~T}, \mathrm{D}$ \\
\hline COXIV & 100 & 11 & 163 & 23 & 196 & 9 & 293 & 11 & $\mathrm{~T}, \mathrm{D}$ \\
\hline
\end{tabular}

HFD, high-fat diet; PGC-1 $\alpha$, PPAR- $\gamma$ coactivator-1 $\alpha$; D, diet effect; $\mathrm{T} \times \mathrm{D}$, tissue and diet interactive effect; Mfn1, mitofusin 1; Fis 1, mitochondrial fission 1; Mfn2, mitofusin 2; TFAM, transcription factor A; T, tissue effect; COXII and COXIV, cytochrome $c$ oxidase subunits II and IV, respectively.

* Levels of the control male rats were set at $100 \%$.

$\dagger P<0.05$.

¥ Mean values were significantly different for the HFD group from those of the control group $(P<0.05$; Student's $t$ test).

$\S$ Mean values were significantly different for the periovarian depot from those of the epididymal depot $(P<0.05 ;$ Student's $t$ test). 


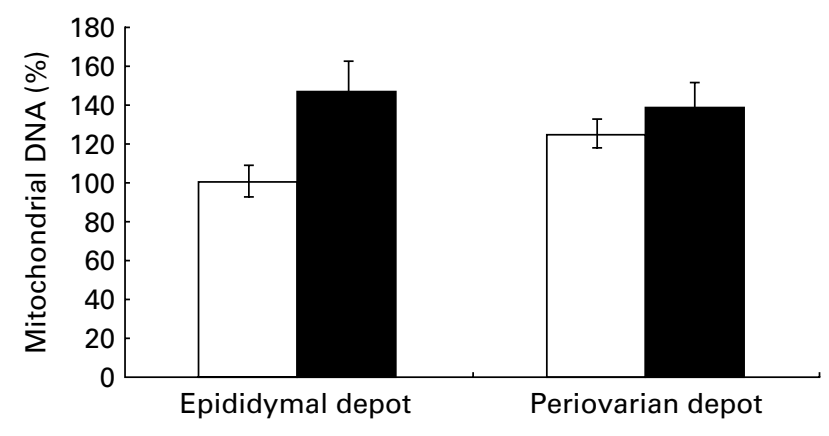

Fig. 2. Gonadal white adipose tissue mitochondrial DNA levels in control animals $(\diamond)$ and high fat diet-fed animals $(\diamond)$. Values are means for eight animals per group, with their standard errors represented by vertical bars. Levels of the control male rats were set at $100 \%$. Mean values were significantly different $(P<0.05$; ANOVA: diet effect $)$.

periovarian depot and decreased after HFD feeding, although this decrease did not reach statistical significance $(P=0 \cdot 058)$.

\section{mRNA and protein levels of gonadal white adipose tissue mitochondrial biogenesis and function markers}

Greater expression levels of PPAR- $\gamma$ coactivator- $1 \alpha$ (Table 8) were observed in the periovarian depot of the control animals compared with the epididymal fat. However, these values increased after HFD feeding only in the latter. This profile agrees with the higher mitochondrial transcription factor A protein levels found in the periovarian depot of the control animals compared with the epididymal one, while the HFD induced an increase in its levels especially in the latter. Both the nuclear-encoded protein COXIV and the mitochondrialencoded protein COXII levels in each cell were higher in the periovarian depot compared with the epididymal one, despite the increase in both sexes after HFD feeding. In the control situation, no significant differences were found between the depots in mtDNA content, whereas it increased after HFD feeding, especially in epididymal fat (Fig. 2). To estimate mitochondrial dynamics, the markers of mitochondrial fusion and fission were determined. Although $M f n 1$ and $M f n 2$ mRNA expression tended to be higher in female rats than in male rats, these differences did not reach statistical significance. The HFD induced an increase in mRNA levels of both factors only in males, reaching higher values than those observed in obese females. Female control rats showed greater expression levels of Fis1 than male rats, increasing after HFD feeding only in males. Interestingly, the Mfn1:Fis1 ratio increased in males after HFD feeding, reaching higher levels than those observed in their female counterparts. No statistical differences were found between the groups in the Mfn2:Fis1 ratio values.

\section{Gonadal white adipose tissue levels of antioxidant enzymes and oxidative damage markers}

Higher levels of catalase, mitochondrial superoxide dismutase and cytosolic superoxide dismutase (Table 9) were observed in periovarian WAT compared with epididymal fat. HFD feeding induced an increase in the levels of antioxidant enzymes in both depots, except in the case of mitochondrial superoxide dismutase. Carbonyl protein content was higher in the epididymal fat compared with the periovarian WAT, and no HFD effects were observed in this parameter. However, no differences between the depots were observed in 4-hydroxy-2nonenal levels, although they increased after HFD feeding in both epididymal and periovarian fat.

\section{Discussion}

The HFD induces a greater increase in gonadal tissue weight gain and adiposity index in female rats compared with male rats (2- $v$. 1.5-fold increase, respectively). The decreased levels of DNA per $g$ tissue associated with the HFD in both depots suggest adipocyte hypertrophy, thus contributing to the buffering of excess lipids from the diet by WAT. The greater increase in serum leptin levels found in females also supports the greater fat accumulation observed in the

Table 9. Gonadal white adipose tissue (WAT) levels of antioxidant enzymes and oxidative damage markers* (Mean values with their standard errors referred to DNA, $n 8$ )

\begin{tabular}{|c|c|c|c|c|c|c|c|c|c|}
\hline & \multicolumn{4}{|c|}{ Epididymal WAT } & \multicolumn{4}{|c|}{ Periovarian WAT } & \multirow[b]{3}{*}{ ANOVA $†$} \\
\hline & \multicolumn{2}{|c|}{ Control } & \multicolumn{2}{|c|}{ HFD } & \multicolumn{2}{|c|}{ Control } & \multicolumn{2}{|c|}{ HFD } & \\
\hline & Mean & SEM & Mean & SEM & Mean & SEM & Mean & SEM & \\
\hline \multicolumn{10}{|l|}{ Antioxidant enzymes (\%) } \\
\hline Catalase & 100 & 5 & 144 & 16 & 136 & 13 & 198 & 16 & $\mathrm{~T}, \mathrm{D}$ \\
\hline GPx & 100 & 8 & 141 & 19 & 134 & 19 & 169 & 11 & D \\
\hline MnSOD & 100 & 9 & 145 & 23 & 185 & 22 & 215 & 18 & $\mathrm{~T}$ \\
\hline CuZnSOD & 100 & 5 & 150 & 23 & 178 & 18 & 231 & 11 & $\mathrm{~T}, \mathrm{D}$ \\
\hline \multicolumn{10}{|l|}{ Oxidative damage (\%) } \\
\hline Carbonyl protein content & 100 & 3 & $86 \cdot 9$ & $6 \cdot 1$ & $64 \cdot 6$ & 4.2 & $69 \cdot 8$ & 4.1 & $\mathrm{~T}$ \\
\hline HNE & 100 & 28 & 228 & 13 & 180 & 14 & 233 & 26 & D \\
\hline
\end{tabular}

HFD, high-fat diet; T, tissue effect; D, diet effect; GPx, glutathione peroxidase; MnSOD and CuZnSOD, mitochondrial and cytosolic superoxide dismutase; HNE, 4-hydroxy-2-nonenal.

* Levels of the control male rats were set at $100 \%$

$+P<0.05$.

$\ddagger$ Mean values were significantly different for the HFD group from those of the control group $(P<0.05$; Student's $t$ test $)$.

$\S$ Mean values were significantly different for females from those of males $(P<0.05$; Student's $t$ test). 
periovarian depot, as this adipokine correlates with the amount of fat accumulated. As a result, the higher expandability capacity pointed out in periovarian WAT, along with the lower lipid accumulation found in peripheral tissues such as liver $^{(14)}$ and muscle ${ }^{(25)}$ of HFD-fed female rats, is in accordance with the capacity of adipose tissue expansion to disrupt lipotoxicity and the development of insulin resistance ${ }^{(39)}$

A HFD induces an increase in the production of adipokines, especially in the epididymal depot, which could have important implications in the systemic and WAT pro-inflammatory ${ }^{(40,41)}$ state and in sex differences found in the insulin sensitivity profile ${ }^{(42,43)}$. In fact, as a consequence of adipose tissue expansion, a hypoxic environment could develop in both depots, since the scarce vascularisation of WAT fails to meet the demand of adipose tissue growth when challenged by a HFD ${ }^{(44)}$. Noticeably, despite the fact that the periovarian depot accumulates more fat than the epididymal one, HIF- $1 \alpha$ levels, major mediators of hypoxia ${ }^{(45)}$, are higher in the latter. In this sense, the 3 -fold increase in HIF-1 $\alpha$ mRNA levels observed in the epididymal WAT in response to the HFD would trigger the activation of angiogenic factors in response to hypoxia ${ }^{(46)}$, and would explain the greater increase in PAI-1 levels observed in this depot, as it is one of the downstream targets of HIF-1 $\alpha^{(7)}$. Indeed, despite its role in providing the stromal matrix necessary to allow the ingrowth of new vascularisation $^{(47)}$, PAI-1 would also have negative effects, since the elevated levels of this factor and therefore the accumulation of fibrin would favour the development of metabolic complications $^{(48)}$ in HFD-fed male rats to a greater extent than in their female counterparts. In fact, although further investigation is still needed to elucidate the specific contribution of each depot to systemic adipokine concentration, gonadal fat could be reflecting what occurs in other depots. In this sense, the mesenteric depot is the most closely related to metabolic complications during obesity due to its portal vein drainage; however, gonadal fat has been seen to contribute to systemic adipokine secretion more than other depots such as subcutaneous and perirenal fat ${ }^{(49-51)}$. HFD-induced hypoxia also contributes to the development of a mild proinflammatory state that becomes particularly evident in epididymal WAT. The greater macrophage infiltration of epididymal fat, suggested by its higher CD68 mRNA levels, is supported by the higher expression levels of $T N F-\alpha$ and $N F-k B$, proinflammatory molecules mainly produced by macrophages, and is also supported by the greater levels of leptin expression that acts as a chemotactic factor ${ }^{(52)}$. Therefore, the lower expandability capacity and the higher pro-inflammatory state developed in the epididymal depot would indicate that this depot is more prone to generate metabolic complications at a systemic level than the periovarian fat.

Beyond the effects already described, hypoxia can also induce mitochondrial biogenesis to cope with hypoxic stress ${ }^{(53,54)}$. Thus, HFD feeding leads to an increase in mitochondrial proliferation and differentiation in epididymal WAT and to mitochondrial differentiation in periovarian WAT, since the increase in mitochondrial machinery content (COXII and COXIV) was not accompanied by an increase in mtDNA levels in the latter. Moreover, the increase in epididymal expression levels of the markers of mitochondrial fusion, Mfn1 and Mfn2 ${ }^{(18,55)}$, as well as in those of PPAR- $\gamma$ coactivator- $1 \alpha$, an upstream regulator of $\mathrm{Mfn}^{(55,56)}$, suggest that changes are happening in this depot not only in mitochondrial machinery content but in mitochondrial morphology as well. In fact, mitochondrial fusion could be protecting the mitochondrial function of the epididymal depot in obese males by promoting mitochondrial oxidative function, as reported previously ${ }^{(57)}$, and also the rapid mixing of membranes and cytosolic components of damaged mitochondria in order to avoid the permanent loss of materials, which would lead to cell dysfunction ${ }^{(58)}$. Indeed, mitochondrial fusion has been related to an increase in mtDNA levels ${ }^{(59-61)}$, which agrees with the higher mtDNA content observed in HFD-fed male rats. On the other hand, the unaltered levels of Mfn1 and Mfn2 observed in obese female rats compared with their control counterparts might indicate that no changes occur in the mitochondrial dynamics of HFD-fed female rats, and are in accordance with the profile of PPAR- $\gamma$ coactivator- $1 \alpha$. Reinforcing this idea, the Mfn1:Fis1 and Mfn2:Fis1 ratio values in the control and obese female rats suggest an equilibrium existing between mitochondrial fusion and fission in response to the HFD that is altered in males by the enhancing effect of the HFD on the Mfn1:Fis1 ratio values. This is in agreement with the idea that Mfn1 is the most efficient Mfn to induce mitochondrial fusion ${ }^{(18)}$. These results suggest the existence of mitochondrial dysfunction in males but not in females, which promotes changes in mitochondrial dynamics (enhanced fusion) and biogenesis (proliferation and differentiation) in epididymal tissue and this would be in agreement with a better metabolic profile of periovarian fat, probably derived from its greater expandability capacity and its lower pro-inflammatory state developed in response to the HFD.

Oxidative stress could be one of the factors involved in alterations caused by the HFD, as suggested by the results of an experiment performed in vitro. Treatment with $\mathrm{H}_{2} \mathrm{O}_{2}$ induces an increase in HIF- $1 \alpha$, PAI- 1 and NF- $\kappa \mathrm{B}$ expression levels in isolated epididymal and periovarian adipocytes from these obese animals, although statistically significant differences were not reached (data not shown). This is in agreement with the increase in these parameters in response to the HFD observed at the tissue level, thus pointing to reactive oxygen species as important effectors of HFD consequences and of the induction of angiogenesis ${ }^{(62)}$ through the regulation of HIF-1 $\alpha$ expression ${ }^{(63)}$. Therefore, the increase in the antioxidant capacity of the gonadal WAT of HFD-fed rats could respond to the potential increase in reactive oxygen species production, underlying the rise in the amount of substrates available for oxidation. Actually, lipid peroxidation increased in both depots, especially in males, suggesting that antioxidant activity would not have been able to avoid oxidative damage.

In agreement with the lower hypoxic and pro-inflammatory state of periovarian fat, female rats manage to maintain a better systemic insulin sensitivity profile than do males, both under control and HFD feeding conditions. The higher serum levels of total adiponectin, an insulin-sensitising factor $^{(3)}$, observed in obese female rats compared with their male counterparts could contribute to this profile. However, in response to HFD feeding, the adiponectin serum level 
profile does not parallel the tissue expression level profile, which suggests that the adiponectin secretion of the gonadal depot would not be the main contributor to the systemic levels. In this sense, results obtained in the same animal model $^{(64)}$ point to the retroperitoneal depot as the greater contributor to systemic adiponectin secretion, in agreement with previous studies ${ }^{(65)}$. Moreover, HFD-fed female rats also exhibit a better insulin sensitivity profile than males, in accordance with their faster clearance of postprandial serum glucose levels pointed out by the results obtained in the oral glucose tolerance test compared with males, thus indicating higher insulin resistance in obese males. However, this dimorphism is not reflected in the levels of key proteins of the insulin signalling pathway of gonadal WAT. This suggests that gonadal WAT is not as sensitive as other tissues or even other WAT depots to the negative effects of the diet, in accordance with what has been observed in previous studies ${ }^{(66)}$ and in the retroperitoneal WAT of these animals ${ }^{(64)}$, in which insulin signalling increases in males and tends to decrease in females. On the other hand, the activation of the adiponectin signalling pathway was compromised by HFD feeding in both depots, as suggested by the decrease in the pAMPK:AMPK ratio (diet effect, $P=0 \cdot 058$ ). Moreover, a positive correlation between high-molecular-weight adiponectin values and the pAMP$\mathrm{K}$ :AMPK ratio was found only in males (Pearson's correlation $0.577, P=0.05)$. In this sense, this could be another fact to support a possible impairment of this signalling pathway in response to the HFD, which suggests the development of adiponectin resistance in the periovarian depot. This idea is further supported by the statistically significant decrease in pAMPK values exhibited by female rats in response to HFD feeding. In fact, the higher levels of adiponectin observed in HFD-fed females did not induce a greater activation of its signalling pathway in gonadal WAT, which would favour the accumulation of lipids instead of their oxidation ${ }^{(67)}$, and, subsequently, the greater expansion of the periovarian depot observed with the HFD. Moreover, given that AMPK has been described to inhibit inflammatory signalling cascades in different cell types ${ }^{(68,69)}$, the higher levels of pAMPK in the periovarian depot compared with the epididymal fat could contribute to the lower degree of inflammation observed compared with the epididymal depot.

Finally, based on the sex/depot-dependent profile observed in the present study, a potential implication of sex hormones in the existence of these differences is quite possible. In fact, oestrogens, specifically $17 \beta$-oestradiol, induce mitochondrial biogenesis and function ${ }^{(70)}$, as well as regulate insulin sensitivity through the oestrogen receptors $\alpha$ and $\beta^{(71,72)}$. Indeed, while oestrogens protect from HFD-induced insulin resistance in mice ${ }^{(73)}$, testosterone inhibits adiponectin production ${ }^{(74)}$. However, further investigation is still needed to elucidate the specific role of these hormones in the overall sexual dimorphism observed in the gonadal WAT depot.

In summary, the present results point to the existence of a sex/depot-dependent response to the HFD in gonadal WAT, which implies that periovarian adipose tissue exhibits a greater expandability capacity than the epididymal depot, which would be related to a lower hypoxic environment and inflammatory profile without signs of mitochondrial dysfunction or changes in mitochondrial dynamics, as well as a better insulin sensitivity profile. This healthier serum and tissue profile in response to HFD feeding could be attributed to the stronger evolutionary pressures to which females have been subjected ${ }^{(75)}$ and that have led them to develop WAT that is genetically programmed to store more lipids and in a safer way than that of males. In contrast, the epididymal WAT of HFD-fed male rats shows a lower expandability capacity and greater inflammation than female rats, thus resulting in a much more detrimental tissue metabolic profile, with changes in mitochondrial dynamics probably associated with HFD-induced mitochondrial dysfunction, thus explaining the worse serum insulin sensitivity profile of male rats. These results demonstrate that gonadal WAT highly reflects the more detrimental effects of HFD feeding on the systemic insulin resistance profile of male rats.

\section{Acknowledgements}

This study was supported by the Dirección General de Investigación y Gestión del Plan Nacional de I + D + i (SAF201021792) and by the Fondo de Investigaciones Sanitarias of the Spanish Government (PIO60293). E. A.-C. was funded by a grant from the Comunitat Autònoma de les Illes Balears. The authors are grateful to Dr Hidetoshi Inagaki for providing the antiserum against the mitochondrial transcription factor A. The contribution of the authors is as follows: I. L., A. M. P. and M. G. designed the study; E. A.-C. conducted the study and performed the data collection and analysis. All authors participated in data interpretation and manuscript writing. The authors declare that they have no conflict of interest.

\section{References}

1. Galic S, Oakhill JS \& Steinberg GR (2009) Adipose tissue as an endocrine organ. Mol Cell Endocrinol 316, 129-139.

2. Trayhurn P \& Wood IS (2005) Signalling role of adipose tissue: adipokines and inflammation in obesity. Biochem Soc Trans 33, 1078-1081.

3. Brochu-Gaudreau K, Rehfeldt C, Blouin R, et al. (2010) Adiponectin action from head to toe. Endocrine 37, 11-32.

4. Gesta S, Tseng YH \& Kahn CR (2007) Developmental origin of fat: tracking obesity to its source. Cell 131, 242-256.

5. Cancello R \& Clement K (2006) Is obesity an inflammatory illness? Role of low-grade inflammation and macrophage infiltration in human white adipose tissue. BJOG 113, 1141-1147.

6. Subramanian V \& Ferrante AW Jr (2009) Obesity, inflammation, and macrophages. Nestle Nutr Workshop Ser Pediatr Program 63, 151-159, discussion 9-62, 259-268.

7. Trayhurn P, Wang B \& Wood IS (2008) Hypoxia and the endocrine and signalling role of white adipose tissue. Arch Physiol Biochem 114, 267-276.

8. Murdoch C, Muthana M \& Lewis CE (2005) Hypoxia regulates macrophage functions in inflammation. J Immunol $\mathbf{1 7 5}, 6257-6263$.

9. Arkan MC, Hevener AL, Greten FR, et al. (2005) IKK-beta links inflammation to obesity-induced insulin resistance. Nat Med 11, 191-198. 
10. Shi H, Kokoeva MV, Inouye K, et al. (2006) TLR4 links innate immunity and fatty acid-induced insulin resistance. J Clin Invest 116, 3015-3025.

11. Hotamisligil GS, Shargill NS \& Spiegelman BM (1993) Adipose expression of tumor necrosis factor-alpha: direct role in obesity-linked insulin resistance. Science 259, 87-91.

12. Feral CC, Neels JG, Kummer C, et al. (2008) Blockade of alpha4 integrin signaling ameliorates the metabolic consequences of high-fat diet-induced obesity. Diabetes 57, $1842-1851$.

13. Bonnard C, Durand A, Peyrol S, et al. (2008) Mitochondrial dysfunction results from oxidative stress in the skeletal muscle of diet-induced insulin-resistant mice. J Clin Invest 118, 789-800.

14. Nadal-Casellas A, Amengual-Cladera E, Proenza AM, et al. (2010) Long-term high-fat-diet feeding impairs mitochondrial biogenesis in liver of male and female rats. Cell Physiol Biochem 26, 291-302.

15. Schrauwen P, Schrauwen-Hinderling V, Hoeks J, et al. (2010) Mitochondrial dysfunction and lipotoxicity. Biochim Biophys Acta 1801, 266-271.

16. Lee HC \& Wei YH (2005) Mitochondrial biogenesis and mitochondrial DNA maintenance of mammalian cells under oxidative stress. Int J Biochem Cell Biol 37, 822-834.

17. Wilson-Fritch L, Burkart A, Bell G, et al. (2003) Mitochondrial biogenesis and remodeling during adipogenesis and in response to the insulin sensitizer rosiglitazone. Mol Cell Biol 23, 1085-1094.

18. Ishihara N, Eura Y \& Mihara K (2004) Mitofusin 1 and 2 play distinct roles in mitochondrial fusion reactions via GTPase activity. J Cell Sci 117, 6535-6546.

19. Yoon Y, Krueger EW, Oswald BJ, et al. (2003) The mitochondrial protein hFis1 regulates mitochondrial fission in mammalian cells through an interaction with the dynaminlike protein DLP1. Mol Cell Biol 23, 5409-5420.

20. Summers SA (2006) Ceramides in insulin resistance and lipotoxicity. Prog Lipid Res 45, 42-72.

21. Nishikawa T, Kukidome D, Sonoda K, et al. (2007) Impact of mitochondrial ROS production in the pathogenesis of insulin resistance. Diabetes Res Clin Pract 77, Suppl. 1, S161-S164.

22. Milagro FI, Campion J \& Martinez JA (2006) Weight gain induced by high-fat feeding involves increased liver oxidative stress. Obesity (Silver Spring) 14, 1118-1123.

23. Esposito K, Ciotola M, Schisano B, et al. (2006) Oxidative stress in the metabolic syndrome. J Endocrinol Invest 29, 791-795.

24. Justo R, Boada J, Frontera M, et al. (2005) Gender dimorphism in rat liver mitochondrial oxidative metabolism and biogenesis. Am J Physiol Cell Physiol 289, C372-C378.

25. Gomez-Perez Y, Amengual-Cladera E, Catala-Niell A, et al. (2008) Gender dimorphism in high-fat-diet-induced insulin resistance in skeletal muscle of aged rats. Cell Physiol Biochem 22, 539-548.

26. Colom B, Alcolea MP, Valle A, et al. (2007) Skeletal muscle of female rats exhibit higher mitochondrial mass and oxidativephosphorylative capacities compared to males. Cell Physiol Biochem 19, 205-212.

27. Nadal-Casellas A, Proenza AM, Gianotti M, et al. (2011) Brown adipose tissue redox status in response to dietaryinduced obesity-associated oxidative stress in male and female rats. Stress 14, 174-184.

28. Justo R, Frontera M, Pujol E, et al. (2005) Genderrelated differences in morphology and thermogenic capacity of brown adipose tissue mitochondrial subpopulations. Life Sci 76, 1147-1158.
29. Justo R, Oliver J \& Gianotti M (2005) Brown adipose tissue mitochondrial subpopulations show different morphological and thermogenic characteristics. Mitochondrion 5, 45-53.

30. Guevara R, Santandreu FM, Valle A, et al. (2009) Sexdependent differences in aged rat brain mitochondrial function and oxidative stress. Free Radic Biol Med 46, 169-175.

31. Llado I, Rodriguez-Cuenca S, Pujol E, et al. (2002) Gender effects on adrenergic receptor expression and lipolysis in white adipose tissue of rats. Obes Res 10, 296-305.

32. Landt M, Gingerich RL, Havel PJ, et al. (1998) Radioimmunoassay of rat leptin: sexual dimorphism reversed from humans. Clin Chem 44, 565-570.

33. Pickavance LC \& Wilding JP (2007) Effects of S 15511, a therapeutic metabolite of the insulin-sensitizing agent $S$ 15261, in the Zucker diabetic fatty rat. Diabetes Obes Metab 9, $114-120$.

34. Thomas PS \& Farquhar MN (1978) Specific measurement of DNA in nuclei and nucleic acids using diaminobenzoic acid. Anal Biochem 89, 35-44.

35. Lowry OH, Rosebrough NJ, Farr AL, et al. (1951) Protein measurement with the Folin phenol reagent. $J$ Biol Chem 193, 265-275.

36. Koekemoer TC, Downing TG \& Oelofsen W (1998) An alternative PCR assay for quantifying mitochondrial DNA in crude preparations. Nucleic Acids Res 26, 2829-2830.

37. Inagaki H, Hayashi T, Matsushima Y, et al. (2000) Isolation of rat mitochondrial transcription factor A (r-Tfam) cDNA. DNA Seq 11, 131-135.

38. Ali TK, Matragoon S, Pillai BA, et al. (2008) Peroxynitrite mediates retinal neurodegeneration by inhibiting nerve growth factor survival signaling in experimental and human diabetes. Diabetes 57, 889-898.

39. Virtue S \& Vidal-Puig A (2010) Adipose tissue expandability, lipotoxicity and the metabolic syndrome - an allostatic perspective. Biochim Biophys Acta 1801, 338-349.

40. Bokarewa M, Nagaev I, Dahlberg L, et al. (2005) Resistin, an adipokine with potent proinflammatory properties. J Immunol 174, 5789-5795.

41. Fantuzzi G (2005) Adipose tissue, adipokines, and inflammation. J Allergy Clin Immunol 115, 911-919; quiz 20.

42. Perez C, Fernandez-Galaz C, Fernandez-Agullo T, et al. (2004) Leptin impairs insulin signaling in rat adipocytes. Diabetes 53, 347-353.

43. Rodriguez A, Catalan V, Becerril S, et al. (2008) Impaired adiponectin-AMPK signalling in insulin-sensitive tissues of hypertensive rats. Life Sci $\mathbf{8 3}, 540-549$.

44. Ye J (2011) Adipose tissue vascularization: its role in chronic inflammation. Curr Diab Rep 11, 203-210.

45. Semenza GL (2004) Hydroxylation of HIF-1: oxygen sensing at the molecular level. Physiology (Bethesda) 19, 176-182.

46. Forsythe JA, Jiang BH, Iyer NV, et al. (1996) Activation of vascular endothelial growth factor gene transcription by hypoxia-inducible factor 1. Mol Cell Biol 16, 4604-4613.

47. Kietzmann T, Samoylenko A, Roth U, et al. (2003) Hypoxiainducible factor- 1 and hypoxia response elements mediate the induction of plasminogen activator inhibitor-1 gene expression by insulin in primary rat hepatocytes. Blood 101, 907-914.

48. Juhan-Vague I \& Alessi MC (1997) PAI-1, obesity, insulin resistance and risk of cardiovascular events. Thromb Haemost 78, 656-660.

49. Gabriely I, Ma XH, Yang XM, et al. (2002) Removal of visceral fat prevents insulin resistance and glucose intolerance of aging: an adipokine-mediated process? Diabetes 51, 2951-2958. 
50. Gui Y, Silha JV \& Murphy LJ (2004) Sexual dimorphism and regulation of resistin, adiponectin, and leptin expression in the mouse. Obes Res 12, 1481-1491.

51. Harris RB, Ramsay TG, Smith SR, et al. (1996) Early and late stimulation of ob mRNA expression in meal-fed and overfed rats. J Clin Invest 97, 2020-2026.

52. La Cava A \& Matarese G (2004) The weight of leptin in immunity. Nat Rev Immunol 4, 371-379.

53. Eells JT, Henry MM, Gross GJ, et al. (2000) Increased mitochondrial K(ATP) channel activity during chronic myocardial hypoxia: is cardioprotection mediated by improved bioenergetics? Circ Res 87, 915-921.

54. Nisoli E, Clementi E, Moncada S, et al. (2004) Mitochondrial biogenesis as a cellular signaling framework. Biochem Pharmacol 67, 1-15.

55. Palmer CS, Osellame LD, Stojanovski D, et al. (2011) The regulation of mitochondrial morphology: intricate mechanisms and dynamic machinery. Cell Signal 23, 1534-1545.

56. Cartoni R, Leger B, Hock MB, et al. (2005) Mitofusins $1 / 2$ and ERRalpha expression are increased in human skeletal muscle after physical exercise. J Physiol 567, 349-358.

57. Pich S, Bach D, Briones P, et al. (2005) The CharcotMarie-Tooth type 2A gene product, $M f n 2$, up-regulates fuel oxidation through expression of OXPHOS system. Hum Mol Genet 14, 1405-1415.

58. Chen H, Detmer SA, Ewald AJ, et al. (2003) Mitofusins Mfn1 and Mfn2 coordinately regulate mitochondrial fusion and are essential for embryonic development. J Cell Biol 160, $189-200$

59. Hori A, Yoshida M \& Ling F (2011) Mitochondrial fusion increases the mitochondrial DNA copy number in budding yeast. Genes Cells 16, 527-544.

60. Chen H, McCaffery JM \& Chan DC (2007) Mitochondrial fusion protects against neurodegeneration in the cerebellum. Cell 130, 548-562.

61. Chen H, Vermulst M, Wang YE, et al. (2010) Mitochondrial fusion is required for mtDNA stability in skeletal muscle and tolerance of mtDNA mutations. Cell 141, 280-289.

62. Ushio-Fukai M \& Alexander RW (2004) Reactive oxygen species as mediators of angiogenesis signaling: role of NAD(P)H oxidase. Mol Cell Biochem 264, 85-97.

63. Bonello S, Zahringer C, BelAiba RS, et al. (2007) Reactive oxygen species activate the HIF-1alpha promoter via a functional NFkappaB site. Arterioscler Thromb Vasc Biol 27, 755-761.
64. Amengual-Cladera E, Lladó I, Gianotti M, et al. (2012) Sex differences in the effect of high-fat diet feeding on rat white adipose tissue mitochondrial function and insulin sensitivity. Metabolism (epublication ahead of print version 6 March 2012).

65. Romero M, Fernandez-Lopez JA, Esteve M, et al. (2009) Different modulation by dietary restriction of adipokine expression in white adipose tissue sites in the rat. Cardiovasc Diabetol 8, 42.

66. Frontini A \& Cinti S (2010) Distribution and development of brown adipocytes in the murine and human adipose organ. Cell Metab 11, 253-256.

67. Gaidhu MP, Frontini A, Hung S, et al. (2011) Chronic AMP-kinase activation with AICAR reduces adiposity by remodeling adipocyte metabolism and increasing leptin sensitivity. J Lipid Res 52, 1702-1711.

68. Salminen A, Hyttinen JM \& Kaarniranta K (2011) AMPactivated protein kinase inhibits NF-kappaB signaling and inflammation: impact on healthspan and lifespan. $J \mathrm{Mol}$ Med 89, 667-676.

69. Peairs A, Radjavi A, Davis S, et al. (2009) Activation of AMPK inhibits inflammation in $\mathrm{MRL} / \mathrm{lpr}$ mouse mesangial cells. Clin Exp Immunol 156, 542-551.

70. Mattingly KA, Ivanova MM, Riggs KA, et al. (2008) Estradiol stimulates transcription of nuclear respiratory factor- 1 and increases mitochondrial biogenesis. Mol Endocrinol 22, 609-622.

71. Barros RP, Machado UF \& Gustafsson JA (2006) Estrogen receptors: new players in diabetes mellitus. Trends Mol Med 12, 425-431.

72. Barros RP, Machado UF, Warner M, et al. (2006) Muscle GLUT4 regulation by estrogen receptors ERbeta and ERalpha. Proc Natl Acad Sci US A 103, 1605-1608.

73. Riant E, Waget A, Cogo H, et al. (2009) Estrogens protect against high-fat diet-induced insulin resistance and glucose intolerance in mice. Endocrinology 150, 2109-2117.

74. Xu A, Chan KW, Hoo RL, et al. (2005) Testosterone selectively reduces the high molecular weight form of adiponectin by inhibiting its secretion from adipocytes. J Biol Chem 280, 18073-18080.

75. Hoyenga KB \& Hoyenga KT (1982) Gender and energy balance: sex differences in adaptations for feast and famine. Physiol Behav 28, 545-563. 